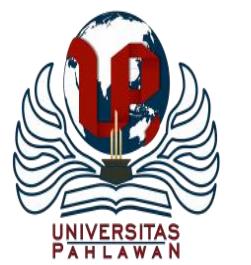

Edukatif : Jurnal Ilmu Pendidikan Volume 3 Nomor 5 Tahun 2021 Halm 2652 - 2663

EDUKATIF: JURNAL ILMU PENDIDIKAN

Research \& Learning in Education

https:/ledukatif.org/index.php/edukatif/index

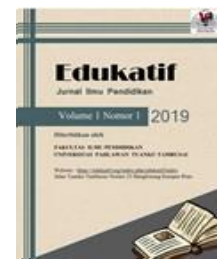

\title{
Implementasi Pembelajaran Bahasa Indonesia menggunakan Model Flipped Classroom Berbasis Pembelajaran Online
}

\author{
N.Supriati ${ }^{1 凶}$, Suci Ramadhanti Febriani ${ }^{2}$ \\ MTsN I Kota Tangerang Selatan ${ }^{1}$ \\ UIN Maulana Malik Ibrahim Malang ${ }^{2}$ \\ E-mail : nsupriati67@gmail.com ${ }^{1}$, $\underline{\text { suciramadhantifebriani11@ gmail.com }}^{2}$
}

\begin{abstract}
Abstrak
Tuntutan inovasi sistem pembelajaran bahasa Indonesia di masa pandemi sangat dibutuhkan. Hal ini bertujuan untuk memberikan hasil belajar yang maksimal meskipun keterbatasan sistem tatap muka di kelas. Atas dasar itu, penelitian ini bertujuan untuk mengeksplorasi implementasi pembelajaran bahasa Indonesia berbasis Flipped Classroom melalui kerangka pembelajaran online dan respon siswa terhadap pembelajaran bahasa Indonesia berbasis Flipped Classroom. Penelitian ini menggunakan desain penelitian kualitatif deskriptif dengan teknik pengumpulan data meliputi wawancara pada 40 siswa, observasi pembelajaran bahasa Indoenesia dan dokumentasi, teknik analisis data yang digunakan melalui proses triangulasi data. Hasil penelitian menunjukkan bahwa proses pembelajaran bahasa Indonesia menggunakan model Flipped Classroom berdampak pada peningkatan hasil belajar yang menunjukkan sebanyak 86,3\% siswa masuk pada kategori lulus mencapai KKM (Kriteria Ketuntasan Minimal), serta respon siswa menunjukkan bahwa sebanyak 85\% merasa senang mengikuti proses belajar menggunakan Flipped Classroom. Temuan penelitian mengindikasikan bahwa proses belajar berbasis Flipped Classroom mampu mempercepat pemahaman siswa dalam memahami konstruksi materi dan penerapannya dalam berbahasa Indonesia.
\end{abstract}

Kata Kunci: Bahasa Indonesia, Flipped Classroom, Pembelajaran Online.

\section{Abstract}

The demand for innovation in the Indonesian language learning system during the pandemic is very crucial. It aims to provide maximum learning outcomes despite the limitations of the face-to-face system in class. On that basis, this study aims to explore the implementation of Indonesian language learning based on Flipped Classroom through an online learning framework and student responses to Indonesian language learning based on Flipped Classroom. This study uses a descriptive qualitative research design with data collection techniques including interviews with 40 students, observations of Indonesian language learning and documentation, data analysis techniques used through the data triangulation process. The results showed that the Indonesian language learning process using the Flipped Classroom model had an impact on improving learning outcomes which showed as many as $86.3 \%$ of students were in the category of passing the KKM (Minimum Completeness Criteria), and student responses showed that as many as $85 \%$ felt happy to follow the learning process. using Flipped Classroom. The research findings indicate that the Flipped Classroom-based learning process is able to accelerate students' understanding in understanding the construction of the material and its application in Indonesian.

Keywords: Indonesia, Flipped Classroom, Online Learning

Copyright (c) 2021 N.Supriati, Suci Ramadhanti Febriani

$\triangle$ Corresponding author

Email : nsupriati67@gmail.com

DOI : https://doi.org/10.31004/edukatif.v3i5.871 


\section{Implementasi Pembelajaran Bahasa Indonesia menggunakan Model Flipped Classroom Berbasis Pembelajaran Online - N.Supriati, Suci Ramadhanti Febriani \\ DOI: https://doi.org/10.31004/edukatif.v3i5.871}

\section{PENDAHULUAN}

Proses peralihan pembelajaran bahasa Indonesia dari sistem tatap muka pada pembelajaran online menuntut guru untuk mengembangkan keterampilan inovasi pembelajaran. Hal ini disebabkan oleh peralihan sistem pengajaran tatap muka pada kerangka pembelajaran online di masa pandemi Corona Virus Disease (COVID)-19 (Dubreil 2020; Pardede 2020). Sebagaimana pembelajaran online sudah banyak ditelaah dan diimplementasikan pada pembelajaran di abad 21 (Lister 2014; Shomurodovich 2020). Hal tersebut menjadi tuntutan keterampilan yang perlu dimiliki peserta didik yakni kolaborasi, komunikasi, berpikir kritis dan kreatif (Daryanto \& Syaiful Karim 2017; Sipayung 2018).

Nurasiah (2020) mengungkapkan bahwa peran guru sangat signifikan dalam meningkatkan pengalaman belajar siswa. Sebagaimana proses pembelajaran Flipped Classroom juga mendorong siswa berkolaborasi untuk meningkatkan komunikasi dan tanggungjawab pada level yang lebih tinggi (Hung, 2015). Selain itu, kegiatan pembelajaran Flipped Classroom juga menuntut siswa memahami dan mengasimilasi informasi. Selama proses belajar, guru juga memberikan umpan balik secara kolektif ketika siswa mengembangkan pemikiran mereka. Flipped Classroom dirancang untuk mengembangkan budaya partisipatif siswa, dan lebih banyak interaksi dengan pengajar dan teman kelompok (Evseeva \& Solozhenko, 2015). Proses tersebut dapat menambah intensitas komunikasi yang tinggi antar siswa dan pengajar maupun antar siswa.

Adapun salah satu kelebihan penerapan pembelajaran Flipped Classroom adalah adanya sistem belajar mandiri. Terkadang siswa berperan menjadi mentor bagi siswa lainnya dalam satu kelompok kecil apabila terdapat teman yang mengalami kesulitan untuk memecahkan permasalahan di kelas. Sehingga proses pembelajaran berpusat pada siswa. Perlunya kolaborasi dan kelompok kecil untuk menyelesaikan tugas atau proyek yang diberikan guru dapat melatih dan membangun kepercayaan diri dan menunjukkan sikap saling menghargai satu sama lain ( $\mathrm{Li}, 2017)$. Hal ini diharapkan mampu memberikan pengembangan keterampilan berbahasa secara maksimal.

Berdasarkan hasil penelitian sebelumnya, Flipped classroom menjadi salah satu alternative kegiatan belajar. Model pembelajaran tersebut merupakan pembelajaran inovatif untuk mengkolaborasikan teknologi dan peningkatan keterlibatan siswa pada proses pembelajaran (Suo \& Hou, 2017). Selain itu, Flipped Classroom juga merupakan strategi pembelajaran aktif yang mengarah pada keterlibatan siswa pada tugastugas yang diinstruksikan guru (Kaya, 2019). Sehingga, adanya proses pembelajaran disampaikan secara online sebelum pengaturan waktu kelas dimulai (Sam, 2016). Selain itu, pembelajaran Flipped Classroom dapat memberikan latihan kolaborasi siswa (Nayar \& Koul, 2020).

Model pembelajaran berbasis Flipped Classroom didasarkan pada integrasi kegiatan kelas tradisional dan online. Kerangka pembelajarannya menuntut guru menyiapkan materi sesuai dengan tujuan pembelajaran. Siswa mengikuti topik pembelajaran di rumah, mereka mencatat, menyiapkan pertanyaan, menyelesaikan kegiatan. Kemudian, mereka berpartisipasi dalam kegiatan yang direncanakan di sekolah meskipun pembelajaran online (Girmen, 2019). Kegiatan berbasis konten e-learning juga diintegrasikan, seperti video, visual, audio dan teks yang disiapkan oleh pengajar dapat disajikan kepada siswa di berbagai platform online atau offline (Kvashnina \& Martynko, 2016). Siswa menyelesaikan tugas-tugas yang berkaitan dengan isi tersebut tanpa memandang waktu dan tempat. Oleh karena itu, ada kesenjangan waktu yang cukup besar di dalam kelas dan guru dapat merencanakan berbagai kegiatan untuk berlatih. Sebagaimana Luhriyani et al., (2020) menjelaskan bahwa proses transformasi pendidikan konvensional ke bentuk digital adalah salah satu alternative pembelajaran di abad 21.

Berpijak dari uraian diatas, pembelajaran Flipped Classroom juga memberikan kesempatan siswa untuk belajar mandiri. Sebagaimana tuntutan belajar yang mereka lakukan sebelum materi disampaikan oleh guru pada waktu pembelajaran di kelas online (Nouri, 2016). Dengan hal itu, siswa dapat menelusuri kemampuan mereka dan mengadopsi berbagai sumber belajar untuk mendukung pemahaman mereka dalam berbahasa. 


\section{Implementasi Pembelajaran Bahasa Indonesia menggunakan Model Flipped Classroom Berbasis Pembelajaran Online - N.Supriati, Suci Ramadhanti Febriani \\ DOI: https://doi.org/10.31004/edukatif.v3i5.871}

Sehingga, proses belajar mandiri juga melatih mereka berpikir kritis untuk menentukan topik yang sesuai dengan pokok bahasan yang dipelajari (Febriani \& Mahmudi, 2021).

Melalui beberapa penelitian sebelumnya, maka masih diperlukan penelitian terkait proses belajar bahasa Indonesia menggunakan sistem Flipped Classroom dengan kerangka belajar online. Atas dasar itu, penelitian ini bertujuan untuk mengeksplorasi implementasi pembelajaran bahasa Indonesia berbasis sistem Flipped Classroom dengan kerangka pembelajaran online dan memetakan respon siswa terhadap proses pembelajaran bahasa Indonesia menggunakan desain Flipped Classroom pada jenjang Sekolah Menengah Pertama/ Madrasah Tsanawiyyah. Sehingga penelitian ini dapat memberikan pedoman bagi implementasi pembelajaran bahasa Indonesia di kelas online.

\section{METODE PENELITIAN}

Berdasarkan tujuan penelitian, maka peneliti menggunakan desain penelitian kualitatif deskriptif. Kehadiran peneliti sebagai instrumen utama dalam pengumpulan data secara langsung. Penelitian dilakukan 2 semester pada tahun pelajaran 2020-2021. Subjek penelitian adalah siswa kelas IX sebanyak 4 kelas dengan pengambilan data secara random sebanyak 40 orang. Data penelitian sepenuhnya dari siswa, yaitu dari nilai PAS (Penilaian Akhir Semester) dan PAT (Penilaian Akhir Tahun), juga dari angket sederhana yg diberikan kepada siswa.

Data penelitian didapatkan melalui angket, observasi dan dokumentasi. Subjek penelitian diambil secara acak yang berjumlah 40 siswa, sedangkan observasi dilakukan untuk melihat implementasi pembelajaran Flipped Classroom, serta dokumentasi terkait proses perencanaan belajar bahasa Indonesia dalam Rencana Pelaksanaan Pembelajaran (RPP). Lokasi penelitian merupakan situasi pembelajaran bahasa Indonesia berbasis online di MTsN I Kota Tangerang Selatan. Proses penggalian data dilakukan dalam bentuk yang bervariasi, yaitu peneliti mengamati proses pembelajaran bahasa Indonesia melalui observasi, kemudian peneliti menyebarkan angket yang berisi susunan pertanyaan terkait topik pembelajaran bahasa Indonesia berbasis Flipped Classroom, setelah itu peneliti melihat konstruksi Rencana Pembelajaran bahasa Indonesia untuk mengidentifikasi tahapan dalam perencanaan, pelaksanaan dan evaluasi belajar berbasis Flipped Classroom.

Teknik analisis yang digunakan menggunakan analisis triangulasi data berdasarkan beberapa langkah, yakni peneliti mengumpulkan data melalui sumber primer dan sekunder terhadap implementasi pembelajaran bahasa Indonesia menggunakan Flipped Classroom, kemudian peneliti mereduksi data yang diperlukan untuk menjawab pertanyaan penelitian, selanjutnya peneliti menyajikan data yang telah didapatkan serta pengambilan kesimpulan setelah adanya proses analisis data (Rahardjo, 2020). Proses pengecekan keabsahan hasil penelitian melalui diskusi peer review bersama teman sejawat serta adanya teknik triangulasi sumber data. Pengecekan tersebut didapati melalui koherensi antara data observasi, wawancara melalui penyebaran angket dan hasil telaah dokumentasi.

\section{HASIL DAN PEMBAHASAN PENELITIAN}

MTsN I Kota Tangerang Selatan sebagai sebuah lembaga pendidikan negeri di bawah naungan Kementerian Agama, sama halnya dengan lembaga pendidikan lain di negeri ini menerapkan pembelajaran online atau daring sejak adanya pandemi COVID-19. Sebelum penerapan Pembelajaran Jarak Jauh secara daring atau pembelajaran dalam situasi normal, waktu belajar di MTsN I Kota Tangerang Selatan dimulai dari pukul 07.00 sampai pukul 15.20 WIB. Dalam satu hari rata-rata siswa belajar di sekolah selama 8 jam 20 menit yang dibagi dalam 10 jam pelajaran dengan dua kali jeda istirahat, yaitu pukul 10.00-10.20 dan pukul 11.50-12.30. Satu jam pelajaran dialokasikan 40 menit. 


\section{Implementasi Pembelajaran Bahasa Indonesia menggunakan Model Flipped Classroom Berbasis Pembelajaran Online - N.Supriati, Suci Ramadhanti Febriani \\ DOI: https://doi.org/10.31004/edukatif.v3i5.871}

Untuk pembelajaran Bahasa Indonesia sesuai dengan yang tertera dalam kurikulum 2013 dialokasikan 6 jam dalam setiap minggu. Apabila dalam satu kali tatap muka dialokasikan dua jam pelajaran, maka siswa akan bertemu dengan pelajaran bahasa Indonesia sebanyak tiga kali dalam setiap minggu. Sangat cukup waktu bagi guru untuk bisa mengeksplor dan membina keterampilan berbahasa Indonesia siswa di kelas. Tapi, kondisi ini berubah sejak penerapan pembelajaran daring. Sekolah mengeluarkan kebijakan pengaturan jadwal pelajaran dengan memangkas waktu belajar, yaitu hanya 3,5 jam saja setiap harinya dimulai pukul 08.00 sampai pukul 11.30. Hal ini berimbas pada pembagian waktu belajar untuk setiap mata pelajaran. Setiap hari siswa belajar 3 mata pelajaran dengan alokasi waktu 60 menit diselingi jeda 15 menit setiap mapelnya, sehingga rata-rata setiap mapel mendapatkan jadwal satu kali dalam satu minggu. Dengan demikian, guru mata pelajaran Bahasa Indonesia pun hanya mendapat alokasi waktu satu kali melakukan pembelajaran jarak jauh secara daring dengan siswa dalam setiap minggunya dengan durasi hanya 60 menit setiap pertemuan, bandingkan dengan jadwal pembelajaran normal, $6 \times 40$ menit $=240$ menit, atau hanya seperempatnya dari waktu normal.

Dengan waktu yang hanya 60 menit dalam satu minggu itulah harus dimaksimalkan supaya hasil pembelajaran sama dengan yang 240 menit dalam situasi normal. Selama semester ganjil dilakukan pembelajaran secara konvensional, yaitu masih Teacher Centered Learning [TCL] yang masih menganut pembelajaran satu arah dimana selama pembelajaran siswa lebih banyak mendengarkan ceramah/penjelasan dari guru. Hal ini mengingat sangat terbatasnya waktu yang tersedia dalam PJJ yang tidak memungkinkan menggunakan model-model pembelajaran kooperatif yang biasa penulis gunakan dalam pembelajaran normal. Sebagai gambaran, PJJ (Pembelajaran Jarak Jauh secara daring) yang dilakukan selama semester ganjil tersebut menggunakan aplikasi Microsoft teams, guru menjelaskan materi dengan bantuan power point, di akhir waktu pembelajaran kalau masih ada waktu, guru melakukan tanya jawab, kemudian sebelum pembelajaran ditutup guru memberikan tugas yang sudah diposting di Microsoft teams kelas untuk dikerjakan siswa di akun masing-masing dengan waktu yang sudah ditentukan. Selama proses pembelajaran, apabila dicek kehadiran siswa yang ikut belajar jumlahnya tidak pernah $100 \%$, paling tinggi jumlah siswa yang ikut belajar hanya mencapai $85 \%$. Dari jumlah yang hadir itu pun ternyata ketika diminta untuk menjawab pertanyaan guru haya 50\% saja yang menjawab, artinya hanya 50\% itulah yang siap belajar, yang lainnya hanya ikut absen kehadiran tapi tidak ikut dalam proses belajar. Ketika pertemuan minggu berikutnya ditanyakan alasan mengapa ketika dipanggil namanya untuk menjawab pertanyaan tidak menyahut? Jawabannya macam-macam, ada yang beralasan sedang ke kamar mandi, ada mengatakan ketiduran, tapi ratarata mereka beralasan sinyal internet jelek, sehingga tidak bisa ikut bergabung dalam pembelajaran sampai selesai.

Di akhir semester ganjil setelah diadakan Penilaian Akhir Semester (PAS), penulis menyebarkan angket singkat dengan 40 orang responden. Dari 40 siswa sebagai responden (dipilih secara acak dari 4 kelas yang diajar oleh penulis, yaitu kelas IX.1, IX.2, IX.3, dan IX.4) yang ditanyakan tentang kesan mereka mengikuti PJJ secara daring selama satu semester [ganjil], diperoleh jawaban sebagai berikut. 


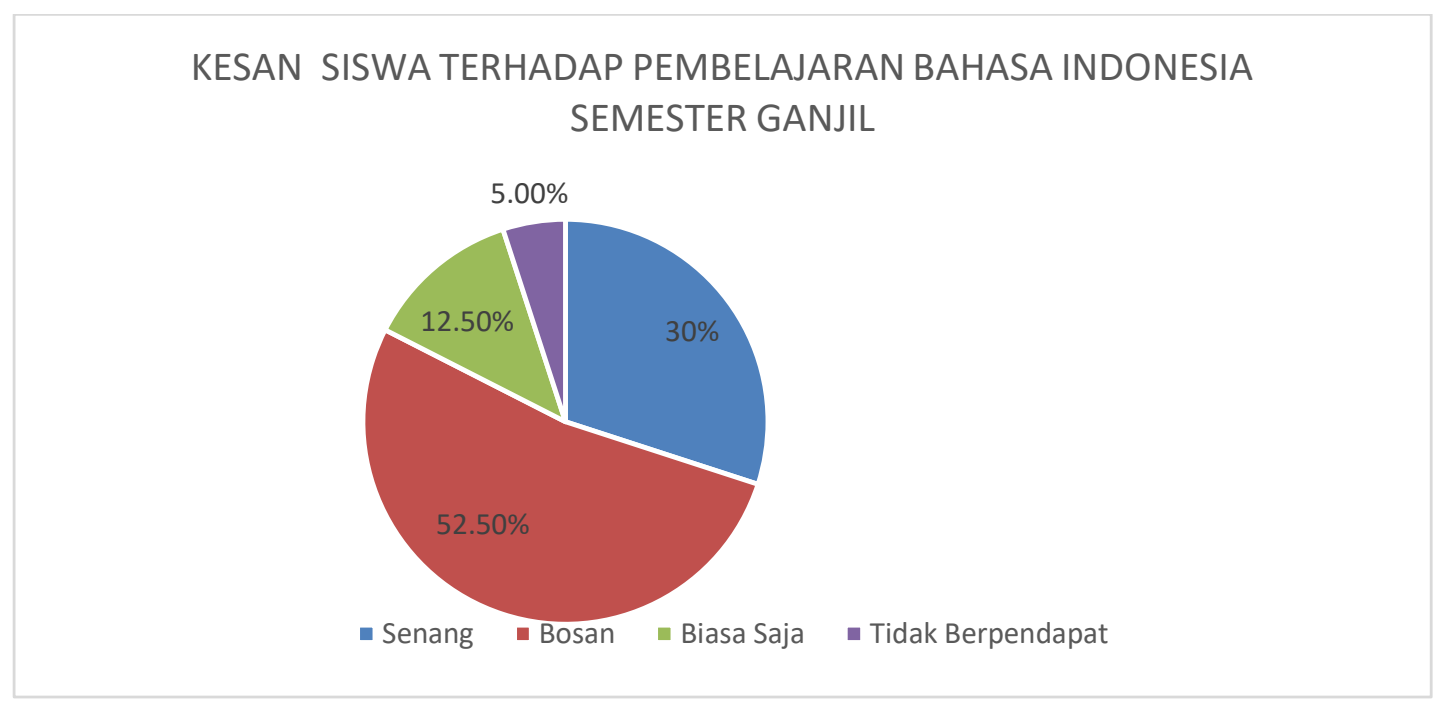

Diagram 1: Kesan Siswa Terhadap Pembelajaran Bahasa Indonesia Semester Ganjil

Berdasarkan diagram tersebut terlihat bahwa sebagian besar siswa, yaitu sebanyak 21 orang $(52,5 \%)$ merasa bosan dengan pembelajaran Bahasa Indonesia dalam PJJ daring. Jumlah ini melebihi separuh dari jumlah responden. Hal ini tentu saja menjadi PR besar bagi penulis selaku guru Bahasa Indonesia di 4 kelas tersebut untuk mencari terobosan model pembelajaan daring yang lebih menantang dan menyenangkan, tidak saja bagi siswa, juga bagi guru sendiri. Adapun presentase siswa yang menjadi responden yang merasa senang dengan pembelajaran Bahasa Indonesia selama PJJ daring hanya 12 orang (30\%), ini sesuatu hal yang di luar dugaan karena biasanya dalam pembelajaran normal hampir 90\% siswa merasa senang ketika belajar Bahasa Indonesia. Ada 5 orang $(12,5 \%)$ yang merasa biasa-biasa saja ketika mengikuti pembelajaran Bahasa Indonesia. Biasa-biasa saja berarti mereka tidak merasa senang dan tidak juga merasa bosan dengan pembelajaran Bahasa Indoesia yang diikutinya selama satu semester tersebut. Dari 40 responden yang ditanya tentang bagaimana kesan mereka ketika mengikuti pembelajaran Bahasa Inonesia selama satu semester, ada 2 orang $(5 \%)$ yang tidak menjawab atau tidak memberikan jawaban.

Ide untuk menanyakan kesan selama pembelajaran ini muncul setelah melihat hasil pembelajaran yang diperoleh dalam PAS (Penilaian Akhir Semester) yang kurang memuaskan, tidak sesuai yang diharapkan. Dengan KKM (Kriteria Ketuntasan Minimal) yang ditetapkan 80, dari 124 siswa yang terdiri dari 26 orang kelas IX.1, 32 orang kelas IX.2, 33 orang kelas IX.3, dan 33 orang kelas IX.4 diperoleh hasil berikut ini.

\section{Perbandingan Nilai Siswa yang Sudah Mencapai KKM dan yang Belum Mencapai KKM pada Semester Ganjil}

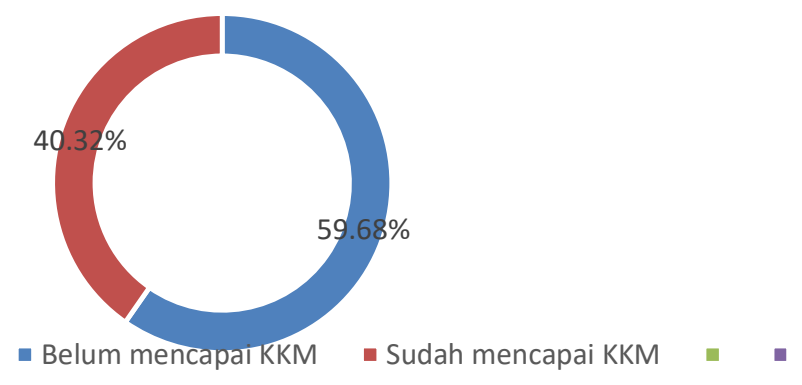

Diagram 2: Perbandingan Nilai Siswa yang Sudah Mencapai KKM dan yang Belum Mencapai KKM Berdasarkan hasil PAS Ganjil. 


\section{Implementasi Pembelajaran Bahasa Indonesia menggunakan Model Flipped Classroom Berbasis Pembelajaran Online - N.Supriati, Suci Ramadhanti Febriani \\ DOI: https://doi.org/10.31004/edukatif.v3i5.871}

Dari diagram tersebut tergambar bahwa jumlah siswa yang berhasil memenuhi KKM lebih sedikit dibandingkan siswa yang tidak memenuhi KKM. Dari jumlah siswa 124 orang, hanya 50 orang [40,32\%] yang sudah mencapai KKM dan sisanya, yaitu 74 orang [59,68\%] masih di bawah KKM. Kalau dikaitkan dengan ketuntasan belajar, idealnya sebuah pembelajaran dikatakan tuntas apabila $75 \%$ dari jumlah siswa berhasil mencapai KKM, maka apabila hanya 40,32\% yang berhasil mencapai KKM berarti pembelajaran Bahasa Indonesia selama semester genap dikatakan tidak berhasil. Perlu diupayakan perbaikan pembelajaran pada semester berikutnya.

Akhirnya, di awal semester genap mulailah digunakan Flipped Classroom (pembelajaran terbalik). Dalam pembelajaran dengan menggunakan model ini, siswa sudah diberikan materi yang harus dipelajari di rumah sesuai tugas yang diberikan guru sebelum siswa belajar di kelas. Model ini juga bisa digunakan guru untuk mengejar ketertinggalan materi bagi siswa yang tidak hadir di kelas. Yang dilakukan penulis dalam menerapkan model Flipped Classroom ini, yaitu dua hari sebelum waktu pembelajaran yang dijadwalkan dalam PJJ, guru sudah mengirimkan materi yang harus dipelajari oleh siswa berikut tujuan pembelajaran yang akan dicapai. Dengan tujuan pembelajaran ini siswa akan tahu apa yang harus mereka pelajari dan apa yang akan mereka lakukan di kelas. Materi yang diberikan bisa berupa teks, power point, atau video. Materi tersebut sudah bisa diakses siswa di Microsoft Teams kelas masing-masing dan dikirim juga melalui ketua kelas untuk dishare di grup WA kelas masing-masing. Sebelum pembelajaran di kelas, siswa diharapkan untuk berdiskusi di grup WA kelas mengenai isi materi atau tugas yang harus mereka lakukan. Ketika pembelajaran di kelas sesuai PJJ, guru hanya memberikan penguatan materi yang kurang dikuasai siswa berdasarkan pertanyaan yang diajukan kemudian siswa bisa langsung melakukan praktik sesuai tuntutan KD di bawah bimbingan guru. Waktu guru untuk membimbing siswa dalam melakukan praktik untuk menguatkan pemahaman menjadi lebih lama. Hal ini karena ketika di kelas siswa sudah datang dengan kondisi $75 \%$ menguasai materi tinggal penguatan saja di bawah bimbingan guru, siswa juga sudah siap dengan apa yang harus mereka lakukan di kelas, misalnya kalau dalam pembelajaran Bahasa Indonesia kelas IX, ketika mempelajari teks tanggapan, mereka sudah siap untuk:

1. Mengidentifikasi informasi berupa kritik, sanggahan, atau pujian dari teks tanggapan

2. Menyimpulkan isi teks tanggapan berupa kritik, sanggahan, atau pujian

3. Menelaah struktur dan kebahasaan dari teks tanggapan

4. Mengungkapkan kritik, sanggahan, atau pujian dalam bentuk teks tanggapan baik secara lisan dan/atau tulisan

Sebagai gambaran, perbedaan aktivitas pembelajaran dengan Flipped Classroomyang dilakukan pada semester genap dan pembelajaran konvensional TCL (Teacher Centered Learning) yang dilakukan selama semester ganjil bisa dilihat dalam tabel berikut ini.

Tabel 1. Perbandingan aktivitas pembelajaran yang dilakukan di kelas dan alokasi waktu dengan Flipped Classroom dan konvensional TCL

\begin{tabular}{|c|c|c|}
\hline No. & $\begin{array}{l}\text { Aktivitas Pembelajaran Jarak Jauh dengan } \\
\text { Flipped Classroom }\end{array}$ & $\begin{array}{l}\text { Aktivitas Pembelajaran Jarak Jauh } \\
\text { Konvensional TCL (Teacher Centered } \\
\text { Learning) }\end{array}$ \\
\hline 1. & $\begin{array}{l}\text { Kegiatan Pendahuluan } 5 \text { (menit) } \\
\text { a. Berdoa } \\
\text { b. Memberikan motivasi }\end{array}$ & $\begin{array}{l}\text { Kegiatan Pendahuluan (5 menit) } \\
\text { a. Berdoa } \\
\text { b. Memberikan motivasi }\end{array}$ \\
\hline 2. & $\begin{array}{l}\text { Kegiatan Inti (45 menit) } \\
\text { a. Pre test secara lisan (5 menit) } \\
\text { b. Siswa dan guru melakukan tanya } \\
\text { jawab tetang teks/power point/video } \\
\text { yang telah ditontonnya [masalah yang } \\
\text { belum terselesaikan melalui diskusi }\end{array}$ & $\begin{array}{l}\text { Kegiatan Inti ( } 45 \text { menit) } \\
\text { a. Pre tes (5 menit) } \\
\text { b. Guru Menjelaskan tujuan } \\
\text { pembelajaran dan menjelaskan } \\
\text { materi pembelajaran, siswa } \\
\text { menyimak ( } 30 \text { menit) }\end{array}$ \\
\hline
\end{tabular}




\begin{tabular}{lll}
\hline $\begin{array}{l}\text { kelompok atau kelas masing-masing] c. } \\
\text { sebagai langkah penguatan } \\
\text { pemahaman siswa terhadap materi } \\
\text { yang dipelajari (10 menit) }\end{array}$ & $\begin{array}{l}\text { praktik/latihan sesuai tuntutan KD } \\
(10 \text { menit }) \text { kalau tidak selesai, } \\
\text { maka harus dilanjutkan di rumah }\end{array}$ \\
c. $\begin{array}{l}\text { Siswa dibimbing guru mengerjakan } \\
\text { praktik/latihan sesuai tuntutan KD } \\
\text { (30 menit) }\end{array}$ & \\
(PR).
\end{tabular}

3. Kegiatan Penutup (10 menit)

a. Post test secara lisan (5 menit)

b. Menyimpulkan \& refleksi (5 menit)
Kegiatan Penutup (10 menit)

a. Post test secara lisan (5 menit)

b. Menyimpulkan \& refleksi (5 menit)

Berdasarkan tabel di atas, terlihat bahwa aktivitas siswa dalam pembelajaran dengan Flipped Classroom (yang dilakukan pada semester genap) lebih aktif daripada dalam kelas konvensional TCL yang dilakukan dalam pembelajaran Bahasa Indonesia pada semester ganjil. Dalam Flipped Classroom, guru hanya bertindak sebagai fasilitator yang mendampingi dan membimbing siswa dalam kegiatan pembelajaran di kelas, yang aktif dalam pembelajaran adalah siswa (Kırmızı \& Kömeç, 2019). Terlihat dalam kegiatan inti, guru hanya memberikan penguatan berdasarkan pertanyaan/masalah yang dihadapi/yang dikemukakan siswa berdasarkan kegiatan yang telah mereka lakukan sebelumnya, yaitu mempelajari materi pelajaran yang sudah disiapkan guru melalui Microsoft Teams sebelum jadwal pertemuan dalam kelas PJJ. Hal ini menumbuhkan kesadaran dan tanggung jawab siswa untuk mau belajar mandiri, mau aktif dalam diskusi kelompok/diskusi kelas sebelum jadwal PJJ dimulai, karena kalau tidak melakukan itu, mereka akan tertinggal jauh dari temantemannya dan tidak bisa melakukan praktik/latihan yang akan dilakukan dalam kelas PJJ. Di samping itu, bagi siswa yang kebetulan dengan alasan tertentu tidak bisa hadir dalam kelas PJJ daring, mereka masih bisa mempelajari materi dari Microsoft Teams atau melalui WA grup kelas masing-masing karena materi sudah juga di share oleh ketua kelas. Selain itu, dalam kegiatan inti dengan Flipped Classroom alokasi waktu bagi siswa untuk melakukan praktik/latihan mendapatkan porsi yang lebih besar, yaitu 30 menit dari 60 menit waktu PJJ, berarti 50\% waktu PJJ dipakai guru untuk membimbing siswa. Dengan demikian diharapkan penguasaan siswa terhadap materi yang dipelajari semakin kuat karena siswa tidak hanya mendengar/menyimak, tetapi juga aktif dalam kegiatan berbahasa yang lain, yaitu membaca, berbicara, dan menulis.

Kalau dilihat aktivitas siswa dalam pembelajaran jarak jauh kelas konvensional lebih banyak menyimak penjelasan guru. Guru menjadi satu-satunya sumber informasi bagi siswa. 50\% dari waktu PJJ guru yang aktif, siswa pasif, kondisi seperti ini membuat siswa bosan dan mengantuk karena harus menatap layar laptop/HP terus-menerus tanpa melakukan aktivitas lain. Hanya tersisa waktu 10 menit (bahkan sering kali tidak ada waktu) untuk siswa melakukan latihan/praktik dengan bimbingan guru, yang akhirnya siswa terpaksa harus mengerjakan latihan ini sebagai PR. Di sinilah penyebab masalah dari keluhan yang sering dilontarkan siswa, yaitu menumpuknya PR/tugas yang harus diselesaikan selama PJJ.

Dalam implementasinya dalam PJJ daring dengan Flipped Classroom, penulis membagi kegiatan menjadi 3 bagian, yaitu kegiatan sebelum kelas PJJ dimulai, kegiatan saat kelas PJJ dimulai, dan kegiatan setelah kelas berakhir. Dalam kegiatan sebelum kelas PJJ dimulai, siswa mempelajari materi/bahan ajar yang akan dibahas di kelas, pada kegiatan sebelum kelas PJJ ini siswa juga diberikan keleluasaan untuk mengakses informasi sebanyak mungkin dari berbagai sumber sebagai tambahan wawasan. Sedangkan kegiatan kedua, yaitu kegiatan saat kelas PJJ, saatnya siswa mengaplikasikan dan menganalisis materi/bahan ajar yang sudah mereka pelajari sebelumnya melalui berbagai kegiatan interaktif di dalam kelas di bawah bimbingan guru. Selanjutnya, bentuk real kegiatan yang dilakukan seperti yang digambarkan dalam tabel 3 di atas. Adapun 
untuk kegiatan setelah kelas PJJ berakhir adalah dilakukan evaluasi (mengisi/menjawab soal Penilaian Harian) yang sudah disiapkan guru di aplikasi Microsoft Teams atau mengerjakan tugas berbasis project yang hasilnya juga diupload siswa di aplikasi Microsoft Teams. Dengan demikian, tahapan ranah kognitif Taksonomi Bloom bisa terlaksana melalui model Flipped Classroom ini, yaitu remembering (mengingat) dan understanding (memahami) pada kegiatan sebelum kelas PJJ dimulai, applying (mengaplikasikan) dan analyzing (menganalisis) pada kegiatan di dalam kelas PJJ, evaluating (evaluasi) dan creating (mencipta) dalam kegiatan setelah kelas PJJ berakhir.

Setelah dilakukan PAT (Penilaian Akhir Tahun) atau ulangan semester genap, ternyata ada peningkatan hasil belajar siswa, baik dari jumlah siswa yang berhasil mencapai KKM maupun nilai rata-rata. Jika sebelumnya (pada hasil PAS) hanya 50 orang yang berhasil mencapai KKM dan 74 sisanya harus menempuh remedial karena nilainya masih di bawah KKM, maka pada PAT jumlah siswa yang mencapai KKM meningkat menjadi 107 orang dan hanya menyisakan 17 orang saja yang belum mencapai KKM. Dengan demikian tentu saja nilai rata-rata pun mengalami peningkatan dari 70,1 pada semester ganjil menjadi 91,93 pada semester genap.

\section{Perbandingan Nilai Siswa yang Sudah Mencapai KKM dan yang Belum Mencapai KKM Pada Semester Genap}

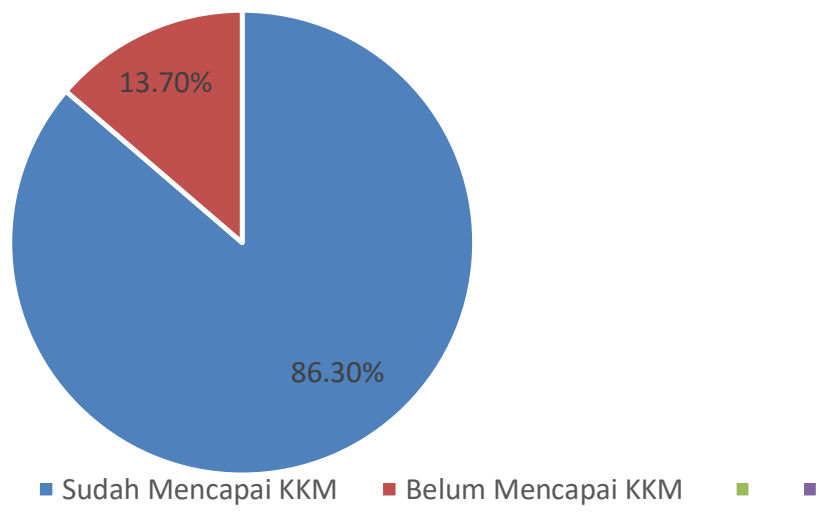

Diagram 3: Perbandingan Nilai Siswa yang Sudah Mencapai KKM dan yang Belum Mencapai KKM Berdasarkan Hasil PAT Semester Genap

Dari diagram di atas terlihat bahwa berdasarkan hasil ulangan semester genap (PAT) jumlah siswa yang berhasil mencapai KKM ada 107 orang, ini berarti sudah 86,3\% siswa yang dinyatakan tuntas dan hanya 17 orang atau $13,7 \%$ saja dari jumlah keseluruhan 124 orang yang masih harus mendapat remedial. Pencapaian ini tentu saja sangat menggembirakan di tengah PJJ dengan banyak kendala yang dialami siswa dan guru.

Yang lebih menggembirakan tentu saja respon siswa terhadap kegiatan PJJ Bahasa Indonesia dengan Flipped Classroom ini menjadi positif. Ketika siswa diberi pertanyaan yang sama seperti yang ditanyakan pada semester ganjil, yaitu, Bagaimana kesanmu selama mengikuti PJJ daring Bahasa Indonesia selama satu semester ini? Jawaban mereka seperti yang terlihat dalam diagram berikut ini. 


\section{Kesan Siswa terhadap Pembelajaran \\ Bahasa Indonesia Semester Genap}

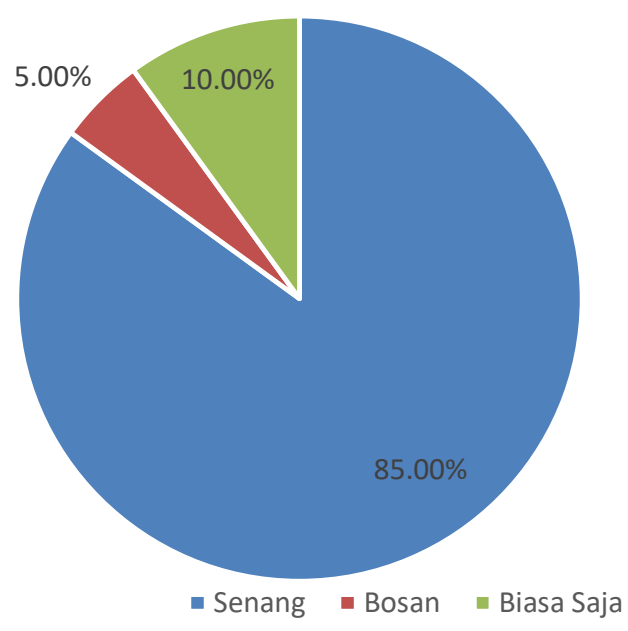

Diagram 4: Kesan Siswa terhadap Pembelajaran Bahasa Indonesia Semester Genap

Berdasarkan diagram tersebut terlihat bahwa dari 40 orang siswa sebagai responden (dipilih secara acak dari 124 oang siswa) yang ditanya tentang kesan mereka selama PJJ mapel Bahasa Indonesia semester genap, 34 orang atau $85 \%$ menjawab senang, 2 orang atau 5\% menjawab bosan, dan 4 orang atau 10\% menjawab biasa-biasa saja. Dengan jawaban ini menunjukkan bahwa PJJ Bahasa Indonesia semester genap sudah memberikan pengalaman pembelajaran yang menyenangkan bagi sebagian besar siswa. Ini berarti Flipped Classroom bisa dijadikan alternatif model pembelajaran dalam PJJ yang dilakukan secara daring.

Berpijak dari temuan penelitian menunjukkan bahwa proses pembelajaran bahasa Indonesia menggunakan desain Flipped Classroom mampu meningkatkan pemahaman siswa dalam belajar. Hal ini didorong oleh kegiatan belajar mandiri yang dilakukan siswa sebelum pembelajaran dimulai. Sebagaimana tingkat pemahaman siswa terhadap materi yang dibaca dan ditelaah berulang akan memberikan konsep yang matang(Asmara, 2016). Flipped Classroom juga mempengaruhi motivasi siswa secara signifikan melalui keinginan dan kesan positif dari pelaksanaan pembelajaran bahasa Indonesia yang dilakukan. Oleh karena itu, inovasi model pembelajaran memberikan kesempatan siswa dan meningkatkan motivasi belajar secara bertahap (Aprianto, 2020).

Adapun penggunaan Flipped Classroom memberikan kesempatan siswa untuk mengontrol pembelajaran mereka sendiri. Mereka bisa belajar melalui aksesibilitas semua sumber daya yang diperlukan dalam lingkungan belajar e-learning. Selain itu, siswa dapat memilih kapan dan di mana belajar dalam batas waktu yang dialokasikan untuk tugas yang bervariasi, sehingga mereka dapat meninjau materi kapan saja mereka membutuhkannya atau mendapatkan bantuan online dari guru atau teman sebaya melalui obrolan dan forum. Hal tersebut merupakan upaya peningkatan kualitas pembelajaran meskipun dalam belajar online. sebagaimana proses belajar online perlu didukung oleh inovasi guru dalam mendesain pembelajaran (Khunaini \& Sholikhah, 2021).

Temuan lainnya menunjukkan bahwa adanya interaksi yang baik antara siswa dengan material jar secara intens. hal ini ditandai oleh pengulangan yang mereka lakukan sebelum proses belajar berlangsung. Proses ini juga menggambarkan usaha positif dalam mengembanhkan potensi siswa melalui proses belajar yang aktif (Sahara \& Sofya, 2020). Selain itu, penelitian lain menginformasikan bahwa adanya peningkatan siswa yang diperoleh dari interaksi terhadap materi ajar yang dipelajari (Suriaman \& Dewi, 2019). Dalam proses pembelajaran bahasa, ditemukan bahwa adanya peningkatan kompetensi berbahasa baik dari sisi aspek 


\section{Implementasi Pembelajaran Bahasa Indonesia menggunakan Model Flipped Classroom Berbasis Pembelajaran Online - N.Supriati, Suci Ramadhanti Febriani \\ DOI: https://doi.org/10.31004/edukatif.v3i5.871}

reseptif yaitu keterampilan menyimak dan membaca maupun keterampilan produktif yaitu berbicara dan menulis. Hal tersebut didukung oleh temuan Vitanofa \& Anwar ( 2017) yang mendeskripsikan bahwa adanya korelasi positif penggunaan Flipped Classroom dengan kemampuan menulis siswa. Sehingga, peningkatan aktivitas siswa dapat membantu pemahaman dan keterampilan siswa.

Penerapan integrasi teknologi dalam Flipped Classroom mendorong kolaborasi antar siswa karena adanya proyek bersama dan pekerjaan kelompok. Julinar \& Yusuf (2019) mengemukakan bahwa keterampilan berbahasa siswa menggunakan desain belajar berbasis Flipped Classroom merupakan salah satu cara belajar yang efektif. Hal tersebut ditandai oleh peningkatan kepercayaam diri siswa dan mengarah pada hasil belajar maksimal. Selain itu, siswa terlibat dalam penilaian peer-to-peer, memberikan umpan balik terhadap hasil kerja teman satu kelompoknya sesuai dengan kriteria yang dikembangkan. Proyek kolaboratif membuat siswa bekerja sama, belajar satu sama lain, dan saling membantu (Andrade 2017; Caruso 2018). Hal tersebut membentuk suasana belajar yang positif dan melatih kemampuan siswa dalam berkolaborasi dalam rangka meningkatkan keterampilan mereka di abad 21 (Rusdin, 2018).

Penelitian ini berimplikasi pada strategi pemilihan belajar yang disesuaikan dengan kebutuhan siswa. Temuan juga menunjukkan adanya peningkatan kualitas belajar menggunakan Flipped Classroom. Akan tetapi, implementasi pembelajaran berbasis Flipped Classroom mendorong para pengajar mampu menguasai teknologi belajar. Hal ini diupayakan untuk mendesain materi berbasis online. Berdasarkan penelitian sebelumnya yang mengungkapkan bahwa upaya pelatihan yang diberikan pada para pengajar dapat menjadi satu pilihan untuk penerapan pembelajaran berbasis online (Febriani et al., 2020; Suriaman \& Dewi, 2019). Sehingga, masih diperlukan penelitian lanjutan menggunakan variabel yang lebih bervariasi dan metode riset yang beragam untuk mendorong inovasi pembelajaran bahasa Indonesia saat ini.

\section{KESIMPULAN}

Berdasarkan hasil temuan, maka penelitian ini menyimpulkan bahwa dampak pembelajaran bahasa Indonesia menggunakan pembelajaran Flipped Classroom menunjukkan hasil belajar positif yang ditandai dengan 86,3\% siswa dapat mencapai Kriteria Ketuntasan Minimal dan sebanyak 85\% siswa menunjukkan motivasi yang positif terhadap penerapan pembelajaran ini. Dengan demikian, temuan penelitian mengindikasikan bahwa penggunaan pembelajaran bahasa Indonesia berbasis Flipped Classroom dengan kerangka belajar online mampu mempercepat pemahaman bahasa Indonesia. Hal itu ditunjukkan melalui besaran tingkatan lulusan dan tingginya motivasi belajar bahasa Indonesia menggunakan Flipped Classroom. Atas dasar itu, penelitian ini masih terbatas pada penerapan belajar bahasa Indonesia dengan sistem Flipped Classroom dan responden yang terbatas. Maka, peneliti merekomendasikan para pengajar bahasa Indonesia untuk mengadakan penelitian lanjutan agar menggunakan variabel dan metode penelitian yang bervariasi.

\section{UCAPAN TERIMA KASIH}

Penulis mengucapkan terimakasih kepada MTsN I Tangerang Selatan yang memberikan dukungan dalam penelitian ini serta para informan yang memberikan informasi terkait data yang diperlukan.

\section{DAFTAR PUSTAKA}

Andrade, M. S. (2017). Online English Language Learning: Theory-Based Course Design And Pedagogy. Journal Of Education And Training Studies, 5(3), 1. Https://Doi.Org/10.11114/Jets.V5i3.2058

Aprianto, D. (2020). To What Extent Does Youtube Contents-Based Language Learning Promote An English Proficiency? Journal Of English Language Teaching And Literature (JELTL), 3(2), 108-126. 
2662 Implementasi Pembelajaran Bahasa Indonesia menggunakan Model Flipped Classroom Berbasis Pembelajaran Online - N.Supriati, Suci Ramadhanti Febriani

DOI: https://doi.org/10.31004/edukatif.v3i5.871

Https://Doi.Org/10.47080/Jeltl.V3i2.994

Asmara, C. H. (2016). EFL Learners' Perception Toward An Outdoor Learning Program. International Journal Of Education And Literacy Studies, 4(2). Https://Doi.Org/10.7575/Aiac.Ijels.V.4n.2p.74

Caruso, L. (2018). Digital Innovation And The Fourth Industrial Revolution: Epochal Social Changes? AI And Society, 33(3), 379-392. Https://Doi.Org/10.1007/S00146-017-0736-1

Daryanto \& Syaiful Karim. (2017). Pembelajaran Abad 21. Gava Media.

Dubreil, S. (2020). Using Games For Language Learning In The Age Of Social Distancing. Foreign Language Annals, 53(2), 250-259. Https://Doi.Org/10.1111/Flan.12465

Evseeva, A., \& Solozhenko, A. (2015). Use Of Flipped Classroom Technology In Language Learning. Procedia - Social And Behavioral Sciences, 206(November), 205-209. Https://Doi.Org/10.1016/J.Sbspro.2015.10.006

Febriani, S. R., \& Mahmudi, A. (2021). Implementasi Pembelajaran Kooperatif Dan Independen Pada Keterampilan Menulis Di Era Revolusi Industri 4.0. Al-Mi'yar, 4(1), 59-72. Https://Doi.Org/10.35931/Am.V4i1.371

Febriani, S. R., Widayanti, R., Amrullah, M. A., \& Mufidah, N. (2020). Arabic Learning For Elementary School During COVID-19 Emergency In Indonesia. OKARA, 14(1), 67-80. Https://Doi.Org/10.19105/Ojbs.V14i1.3194

Girmen, P. (2019). Skills And Enriching Activities : Digital Stories And Games 1. International Journal Of Instruction, 12(1), 555-572. E-Issn: 1308-1470 • Www.E-Iji.Net

Hung, H. T. (2015). Flipping The Classroom For English Language Learners To Foster Active Learning. Computer Assisted Language Learning, 28(1), 81-96. Https://Doi.Org/10.1080/09588221.2014.967701

Julinar, J., \& Yusuf, F. N. (2019). Flipped Learning Model: Satu Cara Alternatif Untuk Meningkatkan Keterampilan Berbicara Siswa. Jurnal Penelitian Pendidikan, 19(3), 366-373. Https://Doi.Org/10.17509/Jpp.V19i3.22330

Kaya, M. F. (2019). Skills And Enriching Activities : Digital Stories And Games 1. 12(1), 555-572.

Khunaini, N., \& Sholikhah, N. (2021). Pengaruh Penggunaan Learning Management System Google Classroom Dan Gaya Mengajar Guru Terhadap Motivasi Belajar Pada Pembelajaran Daring. Edukatif: Jurnal Ilmu Pendidikan, 3(5), 2079-2090.

Kırmızı, Ö., \& Kömeç, F. (2019). The Impact Of The Flipped Classroom On Receptive And Productive Vocabulary Learning. Journal of Language And Linguistic Studies, 15(2), 437-449. Https://Doi.Org/10.17263/Jlls.586096

Kvashnina, O. S., \& Martynko, E. A. (2016). Analyzing The Potential Of Flipped Classroom In ESL Teaching. International Journal of Emerging Technologies In Learning, 11(3), 71-73. Https://Doi.Org/10.3991//jet.V11i03.5309

Li, V. (2017). Social Media In English Language Teaching And Learning. International Journal Of Learning And Teaching. Https://Doi.Org/10.18178/Ijlt.3.2.148-153

Lister, M. (2014). Trends In The Design Of E-Learning And Online Learning. Journal Of Online Learning \& Teaching.

Luhriyani, S., Wahid, A., \& Hajar, A. (2020). Model Pembelajaran Flipped Learning Bagi Guru-Guru SMA $\begin{array}{llllll}\text { Negeri } & 8 & \text { Gowa. Seminar Nasional Pengabdian } & \text {... } & 658-662 .\end{array}$ Http://103.76.50.195/Semnaslpm/Article/View/16076

Nayar, B., \& Koul, S. (2020). Blended Learning In Higher Education: A Transition To Experiential Classrooms. International Journal of Educational Management, 34(9), 1357-1374. Https://Doi.Org/10.1108/JJEM-08-2019-0295 
2663 Implementasi Pembelajaran Bahasa Indonesia menggunakan Model Flipped Classroom Berbasis Pembelajaran Online - N.Supriati, Suci Ramadhanti Febriani

DOI: https://doi.org/10.31004/edukatif.v3i5.871

Nouri, J. (2016). The Flipped Classroom: For Active, Effective And Increased Learning - Especially For Low Achievers. International Journal Of Educational Technology In Higher Education, 13(1). Https://Doi.Org/10.1186/S41239-016-0032-Z

Nurasiah, D., Khuzaemah, E., \& Mulyaningsih, I. (2020). Pengembangan Media Pembelajaran Menulis Teks Ceramah Berbasis Internet Bagi Siswa Kelas XI. ESTETIK: Jurnal Bahasa Indonesia, 3(2), 151. Https://Doi.Org/10.29240/Estetik.V3i2.1756

Pardede, P. (2020). Integrating The 4Cs Into EFL Integrated Skills Learning. 6(March), 71-85. Https://Doi.Org/10.33541/Jet.V6i1.190

Rahardjo, M. (2020). Metodologi Penelitian Kualitatif Untuk Ilmu-Ilmu Sosial Dan Humaniora (Dari Teori Ke Praktik). Republik Media.

Rusdin, N. M. (2018). Teachers' Readiness In Implementing 21 st Century Learning. International Journal Of Academic Research In Business And Social Sciences, 8(4), 1293-1306. Https://Doi.Org/10.6007/Ijarbss/V8-I4/4270

Sahara, R., \& Sofya, R. (2020). Pengaruh Penerapan Model Flipped Learning Dan Motivasi Belajar Terhadap Hasil Belajar Siswa. Jurnal Ecogen, 3(3), 419-431. Http://Ejournal.Unp.Ac.Id/Students/Index.Php/Pek/Article/View/9918

Sam, D. P. (2016). Natural Approach Of Teaching English Language On A Flipped Classroom Platform To Tertiary Level Engineering Learners. International Journal Of Educational Sciences, 14(1-2), 13-18. Https://Doi.Org/10.1080/09751122.2016.11890474

Shomurodovich, N. M. (2020). Using Video Material In Teaching A Foreign Language In Institutions. International Journal On Integrated Education, 3(V), 20-22.

Sipayung, H. D., Sani, R. A., \& Bunawan, W. (2018). Collaborative Inquiry For 4C Skills. 200(Aisteel), 440445. Https://Doi.Org/10.2991/Aisteel-18.2018.95

Suo, J., \& Hou, X. (2017). A Study On The Motivational Strategies In College English Flipped Classroom. English Language Teaching, 10(5), 62. Https://Doi.Org/10.5539/Elt.V10n5p62

Suriaman, A., \& Dewi, A. K. (2019). Peningkatan Keterampilan Membaca Melalui Flipped Classroom Model. $\begin{array}{llll}\text { Jurnal } & \text { Kreatif } & \text { Online, } & 7(4),\end{array}$ Http://Jurnal.Untad.Ac.Id/Jurnal/Index.Php/JKTO/Article/View/14930

Vitanofa, A., \& Anwar, K. (2017). The Effect Of Flipped Learning Through Graphic Organizers Toward Writing Skill At MAN 2 Gresik. Journal Of English Teaching, Literature, And Applied Linguistics, 1(2), 37-49. Http://Journal.Umg.Ac.Id/Index.Php/Jetlal/Article/View/318 